\title{
Differential Responses of CD34-positive Acute Myelogenous Leukemic Blasts to the Costimulating Effects of Stem Cell Factor with GM-CSF and/or IL-3
}

\author{
Yoo Hong Min', Seung Tae Lee', Bong Ki Lee', So Young Chong ${ }^{1}$ \\ Seok Lee', Jee Sook Hahn ${ }^{1}$ and Yun Woong Ko
}

\begin{abstract}
Stem cell factor(SCF), a c-kit ligand, has a preferential effect on the proliferation of several classes of immature hematopoietic progenitor cells in combination with GM-CSF or IL-3. To analyze the costimulatory role of SCF in leukemic growth, we investigated the effect of SCF in the presence of GM-CSF and/or IL-3 on isolated CD34-positive (CD34+) leukemic blasts from 15 patients with acute myelogenous leukemia ( $A M L$ ). Cultures of CD34+ cells from normal bone marrow were used as contrals. When the proliferation of CD34+ AML blasts in the presence of GM-CSF and/or IL-3 were evaluated in vitro for the effects of SCF, two patterns emerged. In one pattern, CD34+ $A M L$ blasts responded with a significant increase in DNA synthesis and/or colony formation when SCF was used with GM-CSF and/or IL-3 relative to the growth with SCF alone; This result is consistent with those CD34+ bone marrow cells from normal donors. Six patients (40\%) were included in this category. The addition of SCF as a single factor resulted in colony formation in all six of these cases. In the ather pattern, nine of the patients (60\%) had CD34+ leukemic cells whose grouth with SCF plus either GM-CSF, IL-3, or GM-CSF + IL-3, was not significantly different from the grouth noted in the presence of SCF alone. Among them seven cases that did not form colonies in response to SCF alone, and one case showing autocrine, background growth were included. In the six cases in which the costimulating effects of SCF were documented, CD34+c-kit+blasts comprised $50.5 \pm 187 \%$ of the CD34+ leukemic blasts - higher than $21.8 \pm 19.4 \%$ of cases in which the costimulating effect of SCF was not documented. In the cases showing high c-kit antigen expression ( $240 \%)$, SCF had a costimulatory effect in $71 \%(5 / 7)$ of the patients. In conclusion, our data indicate that $C D 34+$ leukemic blasts from a good proportion of patients with $A M L$ did not respond to the costimulating effects of SCF in the presence of GM-CSF and/or $I L-3$, in contrast to those CD34+ bone marrow cells from normal donors. The passible use of SCF for acute leukemia must await further cytogenetic and molecular studies, which should clarify the preferential costimulating role of SCF in normal hematopoiesis.
\end{abstract}

Key Words: Acute myelogenous leukemia-CD34+ blasts-Stem cell factor

Received December 29, 1994

Accepted March 7, 1995

Department of Internal Medicine', Microbiology'2, Yonsei University College of Medicine, Seoul Korea

This study was supported in part by a non-directed research fund from the Korean Research Foundation (1993), and in part by a grant from the Myung Sun Kim Memorial Foundation (1994). $+$

Address reprint requests to $\mathrm{Dr}$. YH Min, Department of Internal Medicine, Yonsei University College of Medicine, C.P.O. Box 8044, Seoul 120-752, Korea
Stem cell factor (SCF) is a ligand for the receptor encoded by the $c-k i t$ proto-oncogene found at the dominant White (W) locus on mouse chromosome 5 (Chabot et al. 1988; Geissler et al. 1988). SCF and the c-kit ligand receptor (KR) are thought to play pivotal roles in the regulation of human hematopoiesis. (Williams et al. 1990; Zsebo et al. 1990a). SCF has a preferential effect on the proliferation of several classes of immature 
hematopoietic progenitor cells including the colony-forming unit-Blast (CFU-Blast), the high proliferative potential colony-forming cells (HPP-CFC) and the long-term bone marrow culture-initiating cell (LTBMC-IC) in combination with specific late-lineage cytokines such as interleukin-3 (IL-3) or granulocyte-macrophage colony-stimulating factor (GM-CSF) (Zsebo et al. 1990b; Bernstein et al. 1991; Broxmeyer et al. 1991; McNiece et al. 1991).

Although leukemic progenitor cells in vivo may have apparently escaped normal regulation by stimulatory and inhibitory factors, clonogenic leukemic cell growth of primary leukemias in vitro has been shown to be dependent on hematopoietic growth factors in most cases (Griffin and Löwenberg, 1986; Delwel et al. 1988). There are only a limited number of current studies evaluating the effects of SCF on clonogenic leukemic myeloblasts in vitro (Ikeda et al. 1991; Wang et al. 1991; Carlesso et al. 1992). The addition of SCF as a single factor resulted in only minimal colony growth and DNA synthesis by unseparated clonogenic leukemic precursor cells (Ikeda et al. 1991; Goselink et al. 1992; Tafuri et al. 1993\% the SCF-induced proliferation of acute myelogenous leukemia (AML) cells was significantly augmented by the addition of GM-CSF or IL-3. However, growth of leukemic cells in vitro to SCF in the presence or absence of GM-CSF and/or IL-3 varied from patient to patient (Goselink et al. 1992; Pietsch et al. 1992; Ikeda et al. 1993). In a proportion of AML patients, cells did not respond at all to SCF with GM-CSF and/or IL-3 (Pietsch et al. 1992; Maze et al. 1993). So far, only a few studies have been reported on the growth characteristics of AML CD34-positive (CD34 ${ }^{+}$) cells. Leukemic clonogenic precursors in short-term and long-term cultures were shown to be $\mathrm{CD}_{4}{ }^{+}$(Silvestri et al. 1992; Ikeda et al. 1993), and the proliferative potential for AML cells to SCF in the long-term culture was found to be highly related to the coexpression of CD34 and $c$-kit (Ikeda et al. 1993). To analyze the potential role of SCF in the growth of leukemic progenitor cells in vitro in the presence of late-acting hematopoietic growth factors, we investigated the costimulating effects of SCF with GM-CSF and/or IL-3 on the proliferation of isolated CD34+ leukemic blasts from patients with AML and compared with those of normal BM CD34+ cells. By using this method, the possibility of altering the growth kinetics of AML progenitor cells by endogenous colony stimulating factors from accessory cells can be avoided. If the costimulating effect of SCF is noted preferentially on normal CD34+ bone marrow cells, SCF may be useful in the settings of stem cell transplantation for patients with acute leukemia.

\section{MATERIALS AND METHODS}

\section{Patients and normal donors}

Fifteen patients with AML receiving no drug treatment prior to the study, were included in this investigation (Table 1). They were classified as 3 patients with $\mathrm{Ml}, 8 \mathrm{pa}$ tients with M2, 2 patients with M4, 1 patient with M5, and 1 patient with M6 in accordance to the French-American-British (FAB) classification (Bennet et al. 1985). Their marrow samples were obtained with informed consent. Normal marrow samples for allogeneic bone marrow transplantation were also obtained with informed consent from 10 healthy marrow donors.

\section{Preparation of CD34-positive (CD34+) cell suspension}

The mononuclear cell (MNC) fraction from aspirated bone marrow was collected using the Lymphoprep (Nyegaard, Oslo, Norway) (density $1.077 \mathrm{~g} / \mathrm{cm}^{3}$ ) density gradient centrifugation at $400 \mathrm{~g}$ for 30 minutes. From which the T-cells were removed using $\mathrm{CD} 2$-conjugated immunomagnetic beads (Dynabeads M-450; Dynal A.S., Oslo, Norway). Cytomorphological staining determined that more than $90 \%$ of the cells were leukemic in the BM MNC suspension from patients with AML. Monocyte in normal bone marrow samples was further removed by plastic adherence (Delwel et al. 1988), which was applied for 1 hour at $37^{\circ} \mathrm{C}$ before isolating the CD34+ cells. The CD34+ 
cells were isolated through positive selection using a slightly modified version of Miltenyi's et al (1990) use of immunomagnetic beads. A brief summary of the procedure would be as follows. After adjusting the cell concentration at $4 \times 10^{8}$ nucleated cells $/ \mathrm{ml}$, resuspend the cells in a $300 \mu \mathrm{L}$ phosphate buffer saline solution containing $0.5 \%$ bovine serum albumin (PBS/0.5\% BSA) per $10^{8}$ cells. Next, add $100 \mu \mathrm{L}$ of $F_{c}$.receptor blocking agent (human IgG) and $100 \mu \mathrm{L}$ of $\mathrm{CD} 34$ antibody (clone $8 \mathrm{Gl}$, IgG1) per $10^{8}$ cells, and mix gently. After a $15 \mathrm{~min}$ ute incubation period at $4^{\circ} \mathrm{C}$, carefully wash the cells once in a $400 \mu \mathrm{L}$ buffer. Add $100 \mu \mathrm{L}$ of colloidal supermagnetic MACS microbead (Miltenyi Biotec GmbH, Germany) per $10^{8}$ cells. Mix gently and incubate for 15 minutes at $4^{\circ} \mathrm{C}$. After washing the cells, fill the MiniMACS column (Miltenyi Biotec GmbH, Germany) by pipetting $500 \mu \mathrm{L}$ of buffer on top, and discard the effluent material. Apply the cells to a prefilled MiniMACS column (type MS, without flow resistor), and allow the cells to pass through the column and then wash it 4 times with the $500 \mu \mathrm{L}$ buffer. Remove the column from the separator, and place the column on a suitable tube. Pipette $1 \mathrm{~mL}$ of buffer on top of the column and elute any retained cells using a plunger (CD34+ fraction). For increased sensitivity, this fraction can be passed through the column a second time. The CD34 + cells are then collected in a tube containing $1 \mathrm{~mL}$ of IMDM (Gibco, Grand Island, NY, USA) comprised of $10 \%$ fetal bovine serum(FBS; Gibco, Grand Island, NY, USA). The purity and the phenotypic analysis of the isolated $\mathrm{CD} 34+$ cells were then assessed by flow cytometry.

\section{Immunophenotyping of CD34-positive cells}

A two-color immunophenotyping procedure using directly conjugated MoAbs was performed on the study cells. The portion of CD34+ cells coexpressing CD33, HLA-DR, CD38 and $c$-kit was determined by simultaneously incubating cells with anti-HPCA-2 (CD34)-FITC in combination with either antiLeu-M9(CD33)-PE, anti-Leu-17(CD38)-PE, antiHLA-DR-PE (all from Becton Dickinson), or anti-c-kit-PE (from Im-munotech). Cells stained with the appropriate directly conjugated isotype antibodies were used as controls. Over 10,000 entities were collected in listmode on a FACStar plus (Becton Dickinson, Mountain View, CA) equipped with an argon-ion laser, and analyzed using LYSIS II software (Becton Dickinson). The proportion of $\mathrm{CD} 34+$ cells coexpressing the individual antigens was determined by assessing only cells within the CD34+ gated population.

\section{Recombinant human hematopoietic growth factors}

Recombinant SCF, and recombinant human IL-3 came from Genzyme (Cambridge, MA, USA) and were used at a concentration of $50 \mathrm{ng} / \mathrm{ml}$, and $50 \mathrm{ng} / \mathrm{ml}$, respectively. Recombinant human GM-CSF, kindly provided by Lucky BioTech (Seoul, Korea), was added to each culture at a concentration of $5 \mathrm{ng} / \mathrm{ml}$. Optimal concentration for SCF, IL-3, and GMCSF was chosen after a preliminary doseresponse study of thymidine uptake and colony formation from the normal marow cells (GM-CSF and IL-3), and from the M07E cell line (SCF).

\section{${ }^{3}$ H-Thymidine ( $\left.{ }^{3} \mathbf{H}-\mathbf{T d R}\right)$ incorporation}

The following ${ }^{3} \mathrm{H}-\mathrm{TdR}$ incorporation assay (Delwel et al. 1988) was used to determine the mitogenic activity of SCF. Isolated CD34+ cells were plated in a concentration of $5 \times 10^{3}$ cells $/ \mathrm{ml}$ on 96 -well flat bottom microtiter plates containing an optimal concentration of hematopoietic growth factors (HGFs). The combination of HGFs used are as follows: GM-CSF, IL-3, SCF, GM-CSF+IL-3, GM-CSF+ SCF, SCF+IL-3, and SCF+GM-CSF+IL-3. After incubation for 7 days at $37^{\prime} \mathrm{C}$ in a $5 \%$ $\mathrm{CO} 2 / 95 \%$ atmosphere, the cells were exposed to a 4-hour pulse of $0.5 \mathrm{uCi} 3 \mathrm{H}$-thymidine (25 $\mathrm{Ci} /$ mmol; Amersham, Braunschweig, Germany). Finally, the radioactivity was measured on a scintillation counter (Packrad, Frankfurt, Germany). All assays were performed in triplicate.

\section{Colony assay}

Isolated CD34+ cells were grown at a con- 
centration of $2 \times 10^{3} / \mathrm{ml}$ in methylcellulose composed of IMDM, which in turn consisted of $1.0 \%$ methylcellulose (Methocel $4000 \mathrm{cps}$, Fluka, Germany) supplemented with $20 \%$ heatinactivated FBS, $0.8 \%$ dialyzed bovine serum albumin(BSA) (Sigma, St. Louis, MO), $10^{-4} \mathrm{M}$ 2-mercaptoethanol (Sigma) and HGFs. Various combinations of HGFs were used in thymidine incorporation assay. Cells were plated in $35 \times$ $10 \mathrm{~mm}$ tissue culture dishes (Costar), and then incubated in a fully humidified incubator at $37^{\circ} \mathrm{C}, 5 \% \mathrm{CO}_{2}$. Colonies were enumerated after 14 days of incubation.

\section{Statistics}

Results are expressed as the mean $\pm \mathrm{SD}$. Levels of significance between samples are determined using the non-parametric (MannWhitney) test.

\section{RESULTS}

\section{Purification and analysis of CD34 + cells}

According to flow cytometry analysis, the

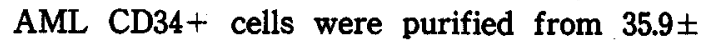
$29.0 \%$ to $94.6 \pm 2.8 \%$ with a $45.5 \pm 30.4 \%$ yield (Table 1). Normal BM CD34+ cells had the purity of $86.2 \pm 14.3 \%$. Double-color fluorescence analysis demonstrated that the majority of purified $\mathrm{CD} 34+\mathrm{AML}$ blasts coexpressed HLA-DR $(87.2 \pm 20.6 \%)$ and CD38 $(86.2 \pm 15.5 \%)$. The majority of normal marrow CD34+ cells also coexpressed HLA-DR, and CD38. CD33 antigen was detectable in $49.5 \pm 35.9 \%$ of CD34+ AML blasts. We found that c-kit expression of CD34+ AML blasts averaged $33.3 \pm 28.6 \%$ with a range from $0.2 \%$ to $89.9 \%$. In normal bone marrow cell samples, $24.4 \pm 8.3 \%$ of $\mathrm{CD} 34+$ cells coexpressed $c$-kit.

Table 1. Phenotype analysis of CD34-positive acute myelogenous leukemic cells after immunomagnetic isolation

\begin{tabular}{cccccccr}
\hline \hline UPN & $\begin{array}{c}\text { Patient } \\
\text { Name }\end{array}$ & FAB & $\begin{array}{c}\text { CD34+ } \\
(\text { Pre })^{*}\end{array}$ & $\begin{array}{c}\text { CD34+/ } \\
\text { CD33+(\%) }\end{array}$ & $\begin{array}{c}\text { CD34+/ } \\
\text { HLA-DR+(\%) }\end{array}$ & $\begin{array}{c}\text { CD34+/ } \\
\text { CD38+/(\%) }\end{array}$ & $\begin{array}{r}\text { CD34+/ } \\
c-k i t+(\%)\end{array}$ \\
\hline 1. & JYM & M1 & 34.1 & 19.6 & 97.8 & 96.8 & 53.6 \\
2. & JYJ & M2 & 45.1 & ND & ND & ND & 67.5 \\
3. & KKS & M1 & 86.4 & 1.2 & 45.6 & 82.5 & 0.2 \\
4. & YKH & M4 & 9.8 & 78.5 & 99.5 & 50.0 & 42.5 \\
5. & CYW & M2 & 61.8 & 51.8 & 98.6 & 99.9 & 20.7 \\
6. & PMR & M2 & 79.4 & 2.9 & 96.8 & 72.0 & 3.7 \\
7. & OJR & M5 & 15.6 & 73.5 & 89.5 & 95.1 & 73.1 \\
8. & KYO & M4 & 1.7 & 14.9 & 95.5 & 91.3 & 21.0 \\
9. & KHS & M2 & 5.2 & 77.5 & 93.3 & 96.1 & 89.9 \\
10. & LNS & M2 & 81.2 & 95.2 & 99.7 & 99.9 & 8.9 \\
11. & KKJ & M1 & 38.0 & 93.1 & 46.1 & 92.3 & 44.1 \\
12. & KJK & M6 & 11.2 & 36.9 & 97.3 & 72.8 & 1.0 \\
13. & SSO & M2 & 22.4 & ND & ND & ND & 45.4 \\
14. & KYS & M2 & 12.5 & ND & ND & ND & 21.0 \\
15. & KSM & M2 & 34.5 & ND & ND & ND & 7.5 \\
\hline Mean & & & 35.9 & 49.5 & 87.2 & 86.2 & 33.3 \\
SD & & & 29.0 & 35.9 & 20.6 & 15.5 & 28.6 \\
\hline
\end{tabular}

UPN: Unique patient number

${ }^{*} \mathrm{CD} 34+$ (Pre) percentage of CD34-positive acute myelogenous leukemic blasts in bone marrow mononuclear cells before purification of CD34-positive cells

$\%$ of cells expressing the indicated surface molecule

ND: not done 
Yoo Hong Min, et al.

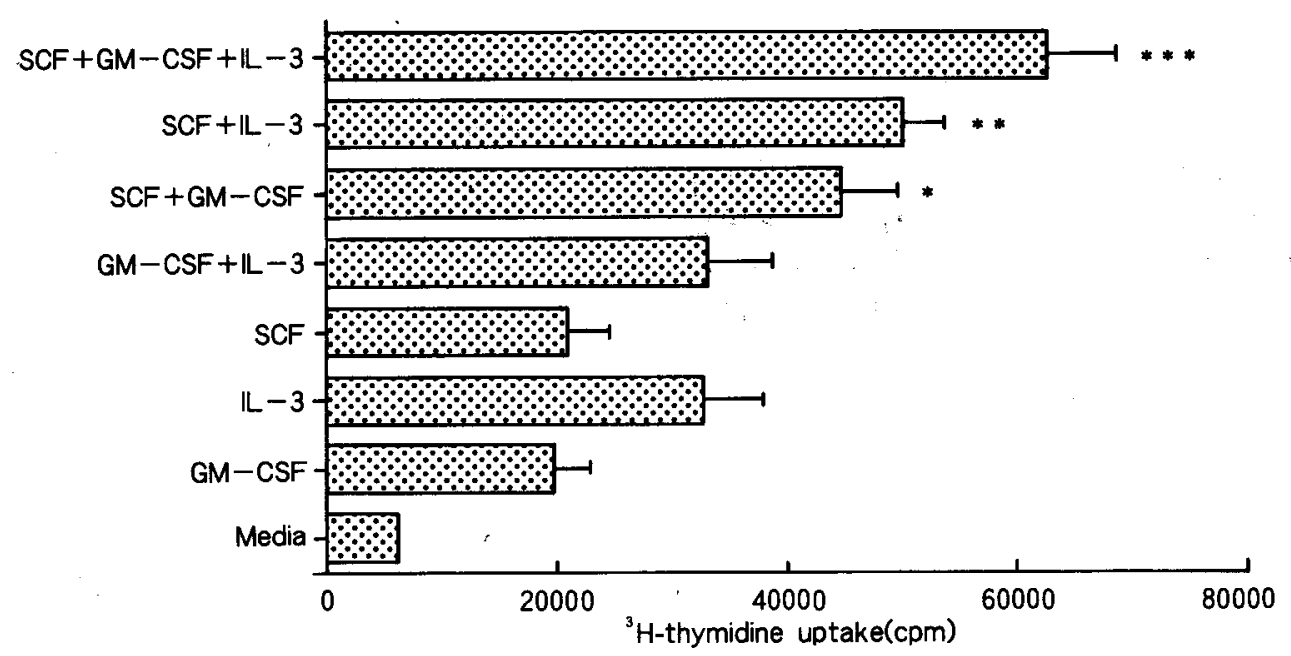

Fig. 1. Effect of SCF alone and in the presence of GM-CSF and/or IL-3 on thymidine uptake from isolated bone marrow $C D 34+$ cells from normal donors. Results reflect the mean number of ${ }^{3} \mathrm{H}$-thymidine incorporation $(\mathrm{cpm})+S D$ of ten experiments after 7-day incubation. *, SCF vs SCF $+G M-C S F, p<0.001 ;{ }^{* *}, S C F$ vs SCF $+I L-3, p<0.001$; ***, $S C F$ vs SCF+GM-CSF+IL-3, $p<0.001$.

Effects of SCF on the proliferation of CD34+ bone marrow cells from normal donors in the presence or absence of GM-SCF and/or IL-3

The influence of SCF upon DNA synthesis and colony formation of CD34+ normal bone marrow cells was studied in the absence or presence of GM-CSF and/or IL-3 (Fig. 1). SCF alone stimulated DNA synthesis (stimulation index above 1.8) in eight out of 10 cases (data not shown). Moreover, SCF alone gave rise to colony-forming unit granulocyte-macrophage (CFU-GM) colonies in eight out of 10 cases. If the number of colonies grown in the presence of GM-CSF was considered as $100 \%$ growth, the addition of SCF as a single factor resulted in $75.1 \pm 28.2 \%$ of colony growth observed with GM-CSF (Fig. 2). When SCF was combined with GM-CSF and/or IL-3, a marked enhancement of DNA synthesis and colony formation was observed in all of the cases studied (Fig. 1, Fig. 2). SCF with GM-CSF ( $p<0.001)$, IL-3 (p $<0.001)$, and GM-CSF plus IL-3 $(\mathrm{p}<0.001)$ had an additive effect upon DNA synthesis and colony formation as opposed to the culture in- itiated with SCF alone. Moreover, the combination of SCF + GM-CSF + IL-3 induced a significant increase in DNA synthesis as opposed to the combination of GM-CSF + IL-3 $(p<0.001)$, SCF + GM-CSF $(p<0.005)$, and SCF + IL-3 $(\mathrm{p}<0.05)$.

Effects of SCF on the proliferation of CD34+ blasts from patients with AML in the presence or absence of GM-SCF and/or IL-3

The influence of SCF on DNA synthesis and colony formation in CD34+ AML cells was studied in the absence or presence of GM-CSF and/or IL-3 (Table 2). SCF stimulated DNA synthesis in isolated CD34 + leukemic blasts in ten out of 15 cases $(66.7 \%)$. In one case that already exhibited high spontaneous proliferation (UPN \#6), SCF did not augment proliferation. SCF stimulated colony formation in eight out of 15 cases $(53.3 \%)$, while GMCSF stimulated colony formation in nine cases. SCF did not stimulate CD34+ AML blasts to form colonies in patients who demonstrated no colony formation under the stimulation of GM-CSF. The addition of SCF as a single factor resulted in $76.8 \pm 36.8 \%$ of colony growth observed with GM-CSF. Aside from 


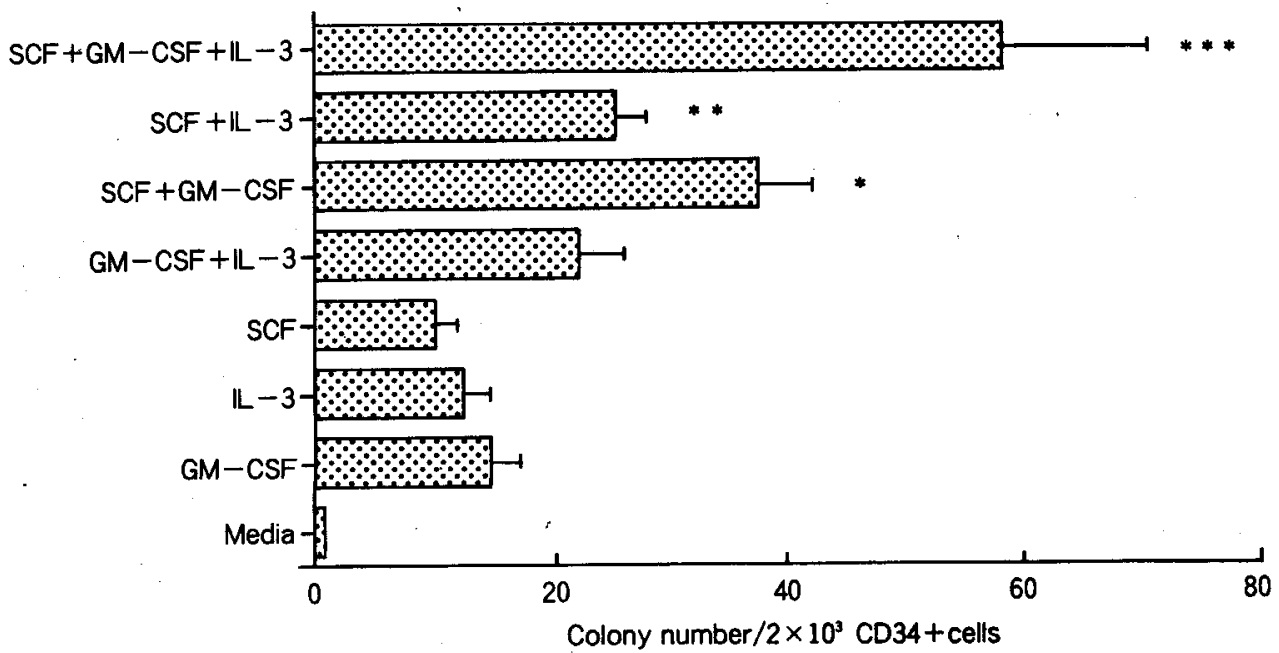

Fig. 2. The effect of SCF alone and in the presence of GM-CSF and/or IL-3 on colony formation from isolated bone marrow CD34+ cells from normal donors. CD34+ cells were plated at 2,000 cells per $m l$ in methylcellulose culture media. Results reflect the mean number of colonies $+S E M$ of 10 experiments scored after 14 day incubation. *, SCF vs SCF+GM-CSF, $p<0.001 ;^{* *}, S C F$ vs SCF+IL-3, $p<0.001 ;{ }^{* * *}, S C F$ vs $S C F+G M-C S F+I L-3, p<0.001$.

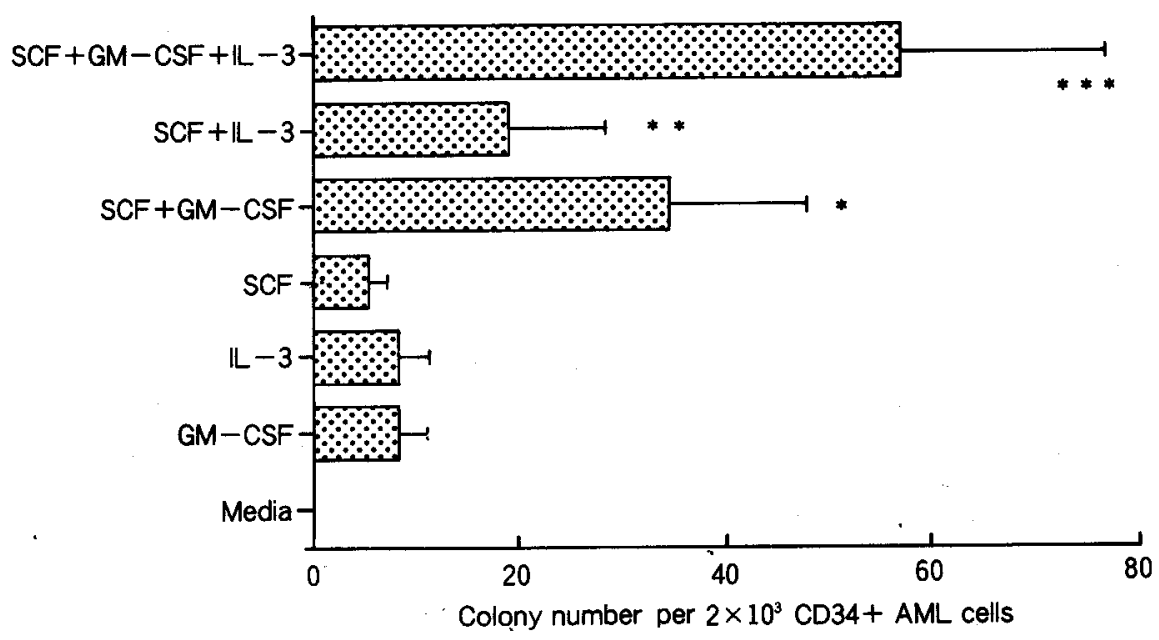

Fig. 3. The effect of SCF alone and in the presence of GM-CSF and/or IL-3 on colony formation from isolated CD34+ $A M L$ blasts from six SCF costimulating responders. Results reflect the mean number of colonies $+S D$ scored after 14 days of incubation. *, SCF vs SCF +GM-CSF, $p<0.05 ;{ }^{* *}$, SCF vs SCF+IL-3, $p<0.05$; ***, SCF vs SCF+GM$C S F+I L-3, p<0.05$.

one (UPN \#12) patient, SCF was less potent than GM-CSF for colony formation. In the absence of added growth factors, cells from only one patient (UPN \#12) formed back- ground colonies.

When the proliferation of $\mathrm{CD} 34+\mathrm{AML}$ blasts in the presence of GM-CSF and/or IL-3 were evaluated in vitro for the effects of 
Table 2. Response of CD34+ acute myelogenous leukemic blasts to the costimulating effects of stem cell factor

\begin{tabular}{|c|c|c|c|c|c|c|c|c|c|}
\hline \multirow{2}{*}{\multicolumn{2}{|c|}{$\begin{array}{l}\text { Unique } \\
\text { Patient } \\
\text { Number }\end{array}$}} & & \multicolumn{7}{|c|}{ Growth of CD34+ AML cells stimulated with } \\
\hline & & & Nothing & GM-CSF & IL-3 & SCF & $\begin{array}{c}\text { SCF+ } \\
\text { GM-CSF }\end{array}$ & $\begin{array}{c}\mathrm{SCF}+ \\
\mathrm{IL}-3\end{array}$ & $\begin{array}{c}\mathrm{SCF}+ \\
\mathrm{GM}-\mathrm{CSF}+\mathrm{IL}-3\end{array}$ \\
\hline \multicolumn{10}{|c|}{ Costimulating Responders } \\
\hline 1 & $3 H-T d R$ & uptake & 687 & 3586 & 912 & 706 & 7907 & 1319 & 10725 \\
\hline & No. of & colony & 0 & 5 & 2 & 3 & 10 & 3 & 8 \\
\hline \multirow[t]{2}{*}{2} & 3H-TdR & uptake & 620 & 2652 & 3093 & 1290 & 15504 & 33716 & 36996 \\
\hline & No. of & colony & 0 & 5 & 3 & 3 & 13 & 5 & 18 \\
\hline \multirow[t]{2}{*}{4} & 3H-TdR & uptake & 6181 & 45028 & 25115 & 14033 & 61950 & 44076 & 73853 \\
\hline & No. of & colony & 0 & 3 & 0 & 2 & 20 & 0 & 23 \\
\hline \multirow[t]{2}{*}{7} & $3 H-T d R$ & uptake & 587 & 1038 & 13824 & 2943 & 719 & 17953 & 736 \\
\hline & No. of & colony & 0 & 5 & 17 & 3 & 15 & 60 & 112 \\
\hline \multirow[t]{2}{*}{13} & $3 \mathrm{H}-\mathrm{TdR}$ & uptake & 497 & 1149 & 1388 & 383 & 1526 & 4050 & 6956 \\
\hline & No. of & colony & 0 & 22 & 8 & 13 & 75 & 23 & 90 \\
\hline \multirow[t]{2}{*}{14} & 3H-TdR & uptake & 7286 & 4939 & 6854 & 4568 & 4489 & 1497 & 5989 \\
\hline & No. of & colony & 0 & 8 & 18 & 7 & 75 & 23 & 90 \\
\hline \multicolumn{10}{|c|}{ Costimulating Nonresponders } \\
\hline \multirow[t]{2}{*}{3} & $3 H-T d R$ & uptake & 524 & 6737 & 800 & 4177 & 3308 & 2660 & 2502 \\
\hline & No. of & colony & 0 & 0 & 0 & 0 & 0 & 0 & 0 \\
\hline \multirow[t]{2}{*}{5} & $3 H-T d R$ & uptake & 171 & 627 & 3532 & 2111 & 469 & 3636 & 476 \\
\hline & No. of & colony & 0 & 3 & 0 & 2 & 3 & 0 & 4 \\
\hline \multirow[t]{2}{*}{6} & 3H-TdR & uptake & 10021 & 5501 . & 16843 & 12230 & 1850 & 21864 & 1683 \\
\hline & No. of & colony & 625 & 0 & 0 & 0 & 0 & 0 & 0 \\
\hline \multirow[t]{2}{*}{8} & 3H-TdR & uptake & 0 & 979 & 1111 & 4171 & 947 & 515 & 1176 \\
\hline & No. of & colony & 0 & 3 & 0 & 0 & 5 & 0 & 4 \\
\hline \multirow[t]{2}{*}{9} & 3H-TdR & uptake & 707 & 1001 & 966 & 2391 & 588 & 2535 & 578 \\
\hline & No. of & colony & 0 & 0 & 0 & 0 & 0 & 0 & 1 \\
\hline \multirow[t]{2}{*}{10} & $3 \mathrm{H}-\mathrm{TdR}$ & uptake & 217 & 7291 & 170 & 4966 & 2865 & 2472 & 1118 \\
\hline & No. of & colony & 0 & 0 & 0 & 0 & 0 & 1 & 1 \\
\hline \multirow[t]{2}{*}{11} & 3H-TdR & uptake & 1830 & 3193 & 10211 & 7347 & 6421 & 11176 & 9159 \\
\hline & No. of & colony & 0 & 0 & 0 & 0 & 0 & 0 & 0 \\
\hline \multirow[t]{2}{*}{2} & $3 H-T d R$ & uptake & 2853 & 1175 & 10285 & 8214 & 1566 & 2222 & 2028 \\
\hline & No. of & colony & 125 & 190 & 175 & 262 & 278 & 273 & 250 \\
\hline \multirow[t]{2}{*}{15} & $3 \mathrm{H}-\mathrm{TdR}$ & uptake & 1111 & 755 & 1623 & 1610 & 1068 & 1736 & 1161 \\
\hline & No. of & colony & 0 & 0 & 0 & 0 & 0 & 0 & 0 \\
\hline
\end{tabular}

AML: Acute myelogenous leukemia

${ }^{*}$ The terms costimulating responders and nonresponders refer to patients whose DNA synthesis and/or colony formation responded or did not respond to the costimulating effect of stem cell factor(SCF) respectively.

${ }^{* 2} \mathrm{CD} 34+$ AML Blasts were cultured in IMDM culture medium $\left(5 \times 10^{3}\right.$ cells $\left./ \mathrm{mL}\right)$ in the presence or absence of various CSFs (see Materials and Methods). Cells were pulsed with [ $\left.{ }^{3} \mathrm{H}\right]$ thymidine for the last 4 hours of 7-day incubation.

${ }^{*}$ The CD34+ AML blasts were incubated at a concentration of $2 \times 10^{3}$ cells $/ \mathrm{mL}$ with individual CSFs. After 14 days of incubation, colonies ( $>40$ cells/group) were counted.

* Data are shown as the median value in triplicate experiments. 
SCF, two patterns emerged. In one pattern, bone marrow $\mathrm{CD} 34+$ leukemic cells responded with a significant increase in DNA synthesis and/or colony formation when SCF was used with GM-CSF and/or IL-3 when compared to growth with SCF alone; This result is consistent with those CD34+ bone marrow cells of normal donors. Six patients $(40 \%)$ were included in this category (Table 2). SCF combined with GM-CSF and/or IL-3 significantly increased the number of colonies as opposed to the effects of SCF alone $(p<0.05)$, of GM-CSF alone $(p<0.05)$, or of IL-3 alone $(p<0.05)$ (Fig. 3). Of the 6 cases, SCF synergized with GMCSF in four cases, with IL-3 in four cases, and with GM-CSF plus IL-3 in four cases for DNA synthesis. In these 4 cases, SCF in combination of GM-CSF and IL-3 appeared to be highly potent mitogenic stimulus of $\mathrm{CD} 34+$ cells. In one case, SCF plus IL-3 resulted in the highest levels of DNA synthesis when compared to the other SCF-cytokine combinations. Except for one case (UPN \#14), the costimulatory effects of SCF, when combined with GM-CSF and/or IL-3, was seen in the colony assay in essentially the same cases that synergy in the thymidine uptake was seen. All of these cases were SCF-responders for colony formation.

In the other pattern, 9 of the patients $(60 \%)$ had CD34+ leukemic cells whose growth with SCF plus either GM-CSF, IL-3, or GM-CSF + IL-3 was not significantly different from the growth noted in the presence of SCF alone, GM-CSF alone, or IL-3 alone. Among them seven cases that did not form colonies in response to SCF alone, and one case (UPN \# 12) showing autocrine, background growth were included.

We evaluated the responsiveness of cells to the costimulating effect of SCF from selected patients by analyzing the coexpression of CD33, HLA-DR, CD38, and c-kit antigen on the same CD34 + leukemic blasts used in this study (Table 1). Expression of CD33, HLA-DR, and $\mathrm{CD} 38$ did not correlate to the costimulating effects of SCF with GM-CSF and/or IL-3. In five cases in which the costimulating effects of SCF was documented, $\mathrm{CD} 34+c-k i t+$ blasts comprised $50.5 \pm 18.7 \%$
$(42.5 \sim 73.0 \%$ ) of the CD34+ leukemic blasts; these tend to be higher than $-21.8 \pm 19.4 \%(1.0$ $\sim 89.9 \%$ ) - the cases in which the costimulating effect of SCF was not documented (Table 1, Table 2). In the cases showing high $c$-kit antigen expression $(\geq 40 \%)$, SCF had a costimulatory effect in $71 \%(5 / 7)$ of the patients.

\section{DISCUSSION}

In the presence of GM-CSF and/or IL-3, the potent costimulating effects of SCF on early hematopoietic progenitor cells in vitro, and the blood cell-stimulating effects of SCF in vivo in animal models (Molinneux et al. 1991; Ulich et al. 1991; Andrews et al. 1992) suggest the usefulness of SCF in certain clinical disorders including acute leukemia requiring enhanced hematopoiesis. There are only a limited number of studies evaluating the effects of $\mathrm{SCF}$ in vitro on hematopoietic progenitor cells from patients with leukemia (Ikeda et al. 1991; Wang et al. 1991; Goselink et al. 1992; Pietsch et al. 1992). c-kit mRNA and encoded surface expression have been described from a number of patients with acute leukemia. In most, if not all cases, it has been reported that in a semisolid medium clonogenic cells from these patients proliferate in response to the effects of SCF when combined with a colony-stimulating factor such as GM-CSF (Carlesso et al. 1992; Goselink et al. 1992). In one report, some variability in res-ponsiveness to SCF has been seen in clonogenic cells from patients with AML, which res-ponded-but to a lesser degree than did cells from patients with chronic myelogenous leukemia and from normal marrow donors(Goselink et al. 1992). In another report (Pietsch et al. 1992), cells from a few AML patients did not respond. All the studies described above were done for the unseparated, heterogenous leukemic cell population. Therefore, evaluation of growth pattern in vitro of rather homogenous, purified leukemic blasts, which have characteristics of progenitor cells, to costimulating effects of SCF should be ensued. It was shown that in short-term and long-term cultures, leukemic clono-genic pre- 
cursors were CD34-positive (Silvestri et al. 1992; Ikeda et al. 1993); furthermore, the proliferative potential of AML cells to SCF in the longterm culture was found to be highly related to the coexpression of CD34 and c-kit (Ikeda et al. 1993). To analyze the potential role of SCF on the growth of leukemic progenitor cells in vitro, we investigated the costimulating effects of SCF with GM-CSF and/or IL-3 upon the proliferation of isolated CD34+ leukemic blasts from patients with $A M L$, and compared those with normal BM CD34+ cells.

As previously stated (Bernstein et al. 1991; Broxmeyer et al. 1991; McNiece, 1991), SCF synergizes with GM-CSF and/or IL-3 when acting on normal $\mathrm{BM}$ CD34+ hematopoietic progenitor cells. When SCF is combined with GM-CSF and/or IL-3, a marked enhancement of DNA synthesis and colony formation was observed in all the cases studied.

When the proliferation of $\mathrm{CD} 34+$ AML blasts in the presence of GM-CSF and/or IL-3 were evaluated in vitro for the effects of SCF, two patterns emerged. In one pattern, bone marrow $\mathrm{CD} 34+$ leukemic cells responded with a significant increase in DNA synthesis and/or colony formation when SCF was used with GM-CSF and/or IL-3 relative to the growth with SCF alone; This result is consistent with those $\mathrm{CD} 34+$ bone marrow cells of normal donors. Six patients $(40 \%)$ were included in this category. Costimulatory effects of SCF in combination GM-CSF and/or IL-3 were also seen in colony assay in essentially the same cases that also showed synergy in the thymidine uptake assay except one case. The addition of SCF as a single factor resulted in colony formation in all six of. these cases. In the other pattern, nine of the patients $(60 \%)$ had $\mathrm{CD} 34+$ leukemic cells whose growth with SCF plus either GM-CSF, IL-3, or GM-CSF + IL-3 was not significantly different from that growth noted in the presence of SCF alone, GM-CSF alone, or IL-3 alone. Our study revealed that the costimulating effect of SCF on CD34 + AML blasts in the presence of GM-CSR and/or IL-3 occured where colonies were formed with \$CF, whereas cells lacking the responsiveness to SCF for colony formation might react defectively with
GM-CSF or IL-3.

It is not clear why CD34+ leukemic cells from a good proportion $(60 \%)$ of patients with AML did not respond to the costimulating effects of SCF. Lack of response may be explained in a number of ways. First, the CD34 + blasts that does not respond may lack SCF-receptors, or may have a low level of $c$ kit expression. Although it was shown that the proliferative response of the unseparated blasts did not correlate with the amount of bound 125I-SCF (Pietsch et al. 1992), the proliferative response of CD34 + AML cells tend to correlate to the extent of $c$-kit expression on the $\mathrm{CD} 34+$ leukemic blasts in our study. In five cases in whom the costimulating effects of SCF was documented, CD34+c-kit + blasts comprised $50.5 \pm 18.7 \%$ of the CD34+ leukemic blasts, which tend to be higher than the $21.8 \pm$ $19.4 \%$ in cases where the costimulating effect of SCF was not documented. All of the responders had $\mathrm{CD} 34+$ leukemic blasts showing high c-kit antigen expression $(\geq 40 \%)$, while only $20 \%$ of the nonresponder had CD34+ cells showing high $c-k i t$ expression. Because the vast majority of $\mathrm{CD} 34+\mathrm{c}$-kit + leukemic blasts evaluated in our study were HLA-DR+, it may be suggested that the costimulating effects of SCF were more prominent in CD34+ HLA-DR $+c$-kit + leukemic myelogenous blasts than in CD34+ HLA-DR + c-kit- blasts, the more differentiated phenotypic subset. In the future, it will become significant to evaluate costimulating ef fects of SCF on more primitive subsets, such as CD34 + HLA-DR-, ckit + leukemic blasts (Brandt et al. 1992; Briddel et al. 1992; Steen et al. 1994), which would investigate the significance of the SCF$c$-kit axis in acute myelogenous leukemia. Second, in contrast to normal CD34 + cells, there may be an abnormal ligand-receptor interaction, where there is a dysregulation of the ckit receptor post-transcriptional regulation and the signal transduction in leukemic CD34+ blasts. Third, the differential costimulating effect of SCF may be mediated by interactions of other cytokines such as IL-4, or TNF(Budel et al. 1993). Fourth, costimulation by dual factors probably triggers additional subsets of CD34+ leukemic cells that does not respond 
to the individual factors. The synergistic proliferative effects of SCF with other cytokines such as GM-CSF or IL-3 appear to be at least partially explained by actions on immediately early gene expression ( $c$-fos, jun-B, c-egr, and $c$ myc) (Horie and Broxmeyer, 1993). Synergistic proliferation of cells in responses to SCF plus GM-CSF or IL-3 does not appear to involve SCF-induced upregulation of GM-CSF or IL-3 receptor number or altered sensitivity to hematopoietic growth factor stimulation (Hendrie et al. 1991; Budel et al. 1993).

In conclusion, CD34+ leukemic blasts from a good proportion of patients did not respond to the costimulating effects of SCF with GMCSF and/or IL-3. However, results do suggest that SCF, in combination with late-acting hemato-poietic growth factors such as GMCSF and/or IL-3, may be useful in the future to preferentially expand ex vivo and in vivo normal hematopoietic stem cell in the settings of stem cell transplantation for patients with acute leukemia. The discovery that SCF has preferential costimulatory effects on $\mathrm{CD} 34+$ AML cells with high levels of c-kit expression and colony-forming capacity in response to SCF should be further investigated. The possible use of SCF in acute leukemia must await further cytogenetic and molecular studies, which should clarify the preferential role of SCF in normal hematopoiesis.

\section{ACKNOWLEDGEMENTS}

We gratefully acknowledge RS Kim, JH Yoo for excellent technical assisstance and HS Lee for flow cytometry. We also thank LuckyGold BioTech. for supplying rhGM-CSF (LBD005).

\section{REFERENCES}

Andrews RG, Bartelmez SH, Knitter GH, Myerson D, Bernstein ID, Appelbaum FR, Zsebo KM: A $c$-kit ligand, recombinant human stem cell factor, mediates reversible expansion of multiple CD34 + colony-forming cell types in blood and marrow of baboons, Blood 80:920:-927, 1992

Bennet JM, Catovsky D, Daniel MT, Flandrin G, Galton DAG, Gralnick H, Sultan C: Proposed revised criteria for the classification of acute leukemia. Ann Intern Med 103: 620-625, 1985

Bernstein ID, Andrews RG, Zsebo KM: Recombinant human stem cell factor enhances the formation of colonies by CD34+ and CD34+lincells cutured with interleukin-3, granulocyte colony-stimulating factor, or granulocyte-macrophage colony-stimulating factor. Blood 77: 23162321, 1991

Brandt J, Briddel RA, Srour EF, Leemhuis TB, Hoffman R: Role of c-kit ligand in the expansion of human hematopoietic progenitor cells. Blood 79: 634-641, 1992

Briddel RA, Broudy VC, Bruno E, Brandt JE, Srour EF, Hoffman R: Further phenotypic characterization and isolation of human hematopoietic progenitor cells using a monoclonal antibody to the c-kit receptor. Blood 79: 3159-3167, 1992

Broxmeyer HE, Cooper S, Lu L, Hangoc G, Anderson D, Cosman D, Lyman SD, Williams DE: Effect of murine mast cell growth factor (c-kit proto-oncogene ligand) on colony formation by human marrow hematopoietic progenitor cells. Blood 77: 142-148, 1991

Budel LM, Delwel R, Buitenen C, Hoogerbrugge H, Lowenberg B: Effects of mast cell growth factor on myeloid leukemia cells in vitro: Effects of combinations with other cytokines. Leukemia 7: 426-434, 1993

Carlesso HM, Williams DE, Fibbe WE, Wessles HW, Beverstock GC, Willemze R, Falkenburg JHF: Effect of mast cell growth factor (c-kit ligand) on clonogenic leukemic precursor cells. Blood 80:750-757, 1992

Chabot B, Stephenson D, Chapman V, Besmer P, Bernstein A: The proto-oncogene $c$-kit encoding a transmembrane tyrosine kinase receptor maps to the mouse w locus. Nature 335: $88-89$, 1988

Delwel R, Salem M, Pellens C, Dorssers C, Wagemaker G, Clark S, Lowenberg B: Growth regulation of human acute myeloid leukemia: Effects of five recombinant hematopoietic factors in a serum-free culture system. Blood 72: 1944-1949, 1988

Geissler EN, Ryan MA, Housman DE: The dominant-white spotting (W) locus of the mouse encodes the c-kit proto-oncogene. Cell 55: 185-192, 1988

Goselink HM, Williams DE, Fibbe WE, Wessels HW, Beverstock GC, Willemz R, Falkenburg JHF: Effect of mast cell growth factor (c-kit 
ligand) on clonogenic leukemic precursor cells. Blood 80:750-757, 1992

Griffin JD, Lowenberg B: Clonogenic cells in acute myeloblastic leukemia. Blood 68: 1185-1195, 1986

Hendrie PC, Miyazawa K, Yang PC, Langefeld CD, Broxmeyer $\mathrm{HE}$ : Mast cell growth factor (c-kit ligand) enhances cytokine stimulation of proliferation of the human factor-dependent cell line, M07e. Exp Hematol 19: 1031-1037, 1991

Horie M, Broxmeyer HE: Involvement of immediate-early gene expression in the synergistic effects of steel factor in combination with granulocyte-macrophage colony-stimulating factor or inter-leukin-3 on proliferation of a human factor-dependent cell line. J Biol Chem 268: 968973, 1993

Ikeda H, Kanakura Y, Tamaki T, Kuriu A, Kitayama H, Ishikawa J, Kanayama $Y$, Yonezawa T, Tauri S, Griffin JD: Expression and functional role of the proto-oncogene $c$-kit in acute myeloblastic leukemia cells. Blood 78: 2962-2968, 1991

Ikeda H, Kanakura Y, Furitsu T, Kitayama H, Sugahara $H$, Nishiura $T$, Karasuno $T$, Tomiyama Y, Yamamotodani A, Kanayama Y, Matsuzawa $Y$ : Changes in phenotype and proliferative potential of human acute myeloblastic leukemia cells in culture with stem cell factor. Exp Hematol 21: 1686-1694, 1993

Maze R, Horie M, Hendrie P, Vadhan-Raj S, Tricot G, Gordon M, Nemunaitis J, Ashman LK, Broxmeyer HE: Differential responses of myeloid progenitor cells from patients with myeloid leukemia and myelodysplasia to the costimulating effects of steel factor in vitro. Exp Hematol 21: 545-551, 1993

McNiece IK, Langley KE, Zsebo KM: Recombinant human stem cell factor synergies with GMCSF, G-CSF, IL-3 and EPo to stimulate human progenitor.cells of the myeloid and erythroid lineages. Exp Hematol 19: 226-231, 1991

Miltenyi S, Muller W, Weichel W, Radbruch A: High-gradient magnetic cell separation with MACS. Cytometry 11: 231-238, 1990

Molinneux G, Migdalska A, Szmitkowski M, Zsebo $K$, Dexter TM: The effects of hematopoiesis of recombinant stem cell factor (ligand for c-kit) administered in vivo to pice either alone or in combination with granulocyte colony-stimulating factor. Blood 78: 961-966, 1991

Pietsch T, Kyas V, Stefféns V, Yakisan E, Hadam MR, Ludwig WD, Zsebo K, Welte K: Effects of human stem cell factor(c-kit ligand) on proliferation of myeloid leukemia cells: heterogeneity in response and synergy with other hematopoietic growth factors. Blood 80: 11991206, 1992

Silvestri F, Banavali S, Yin M, Hulette B, Gopal V, Civin CI, Baccarani M, Preisler HD: CD34 antigen expression of acute myeloid leukemia-colony forming cells. Int J Cell Cloning 1O(Suppl 1): 98-100, 1992

Steen R, Morkrid L, Tjonnfjord GE, Egeland T: $c$ kit ligand combined with GM-CSF and/or IL-3 can expand $\mathrm{CD} 34+$ hematopoietic progenitor subsets for several weeks in vitro. Stem Cells 12: 214-224, 1994

Tafuri A, Felice LD, Mascolo MG, Valentini T, Petrucci MT, Petti MC: Effects of mast cell growth factor on ara-c mediated acute myeloid leukemia cell killing. Stem Cells 11(Suppl 2): 8892, 1993

Ulich TR, Castillo JD, McNiece IK, Yi ES, Alzana $\mathrm{CP}$, Yin S, Zsebo KM: Stem cell factor in combination with granulocyte colony-stimulating factor (CSF) or granulocyte-macrophage colonystimulating CSF synergistically increases granulopoiesis in vivo. Blood 78: 1954-1962, 1991

Wang C, Koistinen $P$, Yang GS, Williams DE, Lyman SD, Minden MD, McCulloch EA: Mast cell growth factor, a ligand for the receptor encoded by $c$-kit, affects growth in culture of the blast cells of acute myeloblastic leukemia. Leukemia 5: 493-497, 1991

Willimas DE, Eisenman J, Barid A, Rauch C, Van Ness K, March CJ, Park LS, Martin U, Mochizucki DY, Boswell HS, Burgess GS, Cocman D, Lyman SD: Identification of a ligand for the c-kit protooncogene. Cell 63: 167 174,1990

Zsebo K, Wypych J, McNiece I, Lu H, Smith K, Karkare S, Sachdev R, Yuschenkoff V, Birkett N, Williams L, Satayagel V, Tung W, Bosselman B, Mendiaz E, Langley K: Identification, purification, and biological characterization of hema-topoietic stem cell factor from buffalo rat liver-conditioned medium. Cell 63 : 195-201, 1990a

Zsebo K, Williams D, Geissler E, Broudy V, Martin F, Atkins H, Hsu R-Y, Birkett N, Okino K, Murdock D, Jacobson F, Langley K, Smith K, Takeishi T, Cattanach B, Galli S, Suggs S: Stem cell factor is encoded at the Sl locus of the mouse and is the ligand for the c-kit tyrosine kinase receptor. Cell 63:213-224, 1990b 